at Viborg in 1907, a lecturer at the Helsinki Technical High School in 1923, a teacher at the University in 1925 and in 1936, the first holder of the chair of physical and electro-chemistry in the University. $\mathrm{He}$ also worked as a student at Dresden, Breslau, Copenhagen and Zurich.

Sihvonen's scientific work was concerned almost exclusively with the oxidation of carbon. Inspired by Langmuir's experiments upon the combustion of carbon filaments in oxygen at low pressure, Sihvonen attempted by similar, more elaborate methods, to gain a deeper insight into the primary mechanism of carbon oxidation. He carried out both static and dynamic experiments, the results of which are published in a large number of papers which have appeared since 1930 . In order to explain the relative amounts of carbon monoxide and dioxide formed in these experiments he elaborated a detailed theory which involves the formation of ketone and ketene groupings on the border carbon atoms. His studies included experiments upon the oxidation of graphite and diamond by oxygen in the presence of X-radiation, and the oxidation of carbon by steam and in fused electrolytes. $\mathrm{He}$ also made a study of the electrolytic oxidation of tartaric acid and alkali tartrates.

Sihvonen visited Great Britain as recently as 1938 on the occasion of the Faraday Society's general discussion at Bristol upon "Chemical Reactions Involving Solids" when everyone was impressed by his quiet, friendly, unassuming manner. He was a member of the Suomalainen Tiediakatemia and had rendered his country great service in the Finnish war of independence. His tragic death deprives Finland of an outstanding scientific worker and a distinguished teacher.

\section{Mr. J. A. Hobson}

John Atrinson Hobson, who died on April 1, was one of the most distinguished among British economists, although he never held any regular academic post and had to wait until the last years of his life for his fellow economists to recognize the importance of his work. Born at Derby on July 6, 1858 , Hobson, on leaving Oxford, spent seven years as a schoolmaster, and thereafter for ten years was engaged chiefly in extension lecturing and teaching for the Universities of London and Oxford.

The first book published byHobson, "The Physiology of Industry" (1889) was written in collaboration with the late A. F. Mummery, well known as business man and Alpine climber; and it contained the germ of his later work. Hobson was already putting forward in 1889 that theory of 'underconsumption' which was for many years to be ridiculed by the great majority of professional economists, though the very great element of truth contained in his theory has in recent years been widely appreciated, and there is a close resemblance at a number of points between his doctrines and those enunciated by $\mathrm{Mr}$. J. M. Keynes in his more recent work. Hobson developed his views in many later books, among which the most important are "The Industrial System" (1909), "The Science of Wealth" (1911) and "Work and Wealth : a Human Valuation" (1914).

In the general approach to economic problems, Hobson was greatly influenced by Ruskin, and he treated economics not as a self-contained science, but rather as a branch of social science as a whole. His works contained much acute criticism of the narrowness of modern orthodox economic theory, and he was continually insisting on the need to approach economic problems from the point of view of human welfare in the broadest sense. Outside the field of economic theory he wrote widely; and at least two of his books have become historical classics. These are "The Evolution of Modern Capitalism" (1894) and "Imperialism" (1902). They remain the most penetrating studies yet written in their respective fields.

During the War of 1914-18, Hobson was actively associated with the Union of Democratic Control, in which he continued to take a lively interest up to the time of his death. He wrote extensively for the Manchester Guardian, and was for a long time one of the leading theorists of advanced Liberalism. In his later years, however, he had come to accept a Socialist position, led thereto by the conviction that the capitalist system was essentially restrictive in its working, and was therefore incapable of emancipating itself from the vice of underconsumption.

Hobson, on several occasions, lectured in American universities : indeed, his work was, until quite lately, much better appreciated in the United States than in Great Britain. Personally, he was a man of exceptional charm, with a very lively wit and great capacity for friendship. His series of war-time dialogues, published in the Nation during the War of 1914-18 under the name "Lucian", showed how wittily he could write when he chose.

G. D. H. Cole.

\section{Colonel C. T. Green}

THE death of Colonel Conrad Theodore Green, in his seventy-seventh year, at Birkenhead on April 17, removes one of the best known of Merseyside botanists, for at his own cost and initiative he edited the 1902 and 1933 editions of "The Flora of Liverpool". An active member of many national and local societies, he was a past president of the Liverpool Botanical Society and other societies, and on the executive council of Flora's Leagiue he assisted Sir John Abbot-Anderson in the national protection of wild plants by lecturing in numerous parts of the country.

Born at Kirkburton, West Riding, in 1863, Dr. Green obtained a medical practice in Birkenhead in 1887 ; he was elected to the Linnean Society in 1901 ; and, after pre-War duty as medical officer in the Territorial Army, he was promoted Colonel, Army Medical Service, in 1915. In 1905 the Chester Society of Natural Science awarded him the Kingsley Medal, for botanical research. He made a long series of microscope slides of micro-fungi attacks upon plants for that Society. 